\title{
PATHOLOGICAL EFFECTS OF Echinostoma paraensei INFECTION ASSOCIATED WITH PYOGENIC ABSCESSES CAUSED BY Pseudomonas aeruginosa IN SWISS MICE
}

\author{
Juberlan Silva Garcial, Raquel de Oliveira Simões ${ }^{2}$,Ester Mota ${ }^{3}$, Incerlande \\ Soares dos Santos ${ }^{4}$ and Arnaldo Maldonado Júnior ${ }^{1}$
}

\section{ABSTRACT}

The trematode Echinostoma paraensei is an intestinal parasite transmitted by ingestion of the infectious stage of metacercariae. For scientific purposes, its life cycle has been maintained in the laboratory, allowing analysis using various biological approaches. Different parasite isolates have revealed atypical patterns of migration and establishment in ectopic sites in SwissWebster mice. During the investigation of the biological life cycle of an E. paraensei isolate from the silvatic rodent Nectomys squamipes collected in the municipality of Rio Bonito (State of Rio de Janeiro), a bacterial coinfection with Pseudomonas aeruginosa was observed, which produced anatomopathological alterations, mainly in the liver, bile ducts, pancreas, and small intestine. The main macroscopic signs were the whitish suppurative pyogenic punctual lesions. The histological sections stained by hematoxylin-eosin showed an intense inflammatory reaction formed by mononuclear cells and macrophages surrounding the bile ducts, although the hepatic parenchyma still presented its normal aspect. Thus, pyogenic abscesses can be associated with $E$. paraensei infection depending on the strain and aggravating pathogenesis in the definitive host.

KEY WORDS: Liver abscess; Swiss mice; trematode infection.

\footnotetext{
1. Fundação Oswaldo Cruz, Instituto Oswaldo Cruz, Laboratório de Biologia e Parasitologia de Mamíferos Silvestres, Rio de Janeiro, RJ, Brazil.

2. Universidade Federal Rural do Rio de Janeiro, Departamento de Parasitologia Animal, Seropédica, RJ, Brazil.

3. Fundação Oswaldo Cruz, Instituto Oswaldo Cruz, Laboratório de Patologia, Rio de Janeiro, RJ, Brazil.

4. Fundação Oswaldo Cruz, Instituto de Ciência e Tecnologia em Biomodelos, Serviço de Controle da Qualidade Animal, RJ, Brazil.
}

Juberlan da Silva Garcia - ORCID: https://orcid.org/0000-0002-8841-2557, Raquel de Oliveira Simões - ORCID: https://orcid. org/0000-0001-5130-3341, Ester Mota - ORCID: https://orcid.org/0000-0003-0712-3874, Incerlande Soares dos Santos - ORCID: https://orcid.org/0000-0002-3588-1122, Arnaldo Maldonado Júnior - ORCID: https://orcid.org/0000-0003-4067-8660.

Corresponding author: Raquel de Oliveira Simões. E-mail: raquel83vet@gmail.com

Received for publication: 10/8/2020. Reviewed: 18/11/2020. Accepted: 18/1/2021 


\section{INTRODUCTION}

Echinostomiasis is an intestinal trematodiasis caused by several species of Echinostoma, mainly in Asia (Fried \& Graczyk, 2000; Sripa et al., 2010; Sah et al., 2018). In Brazil, the life cycle of some species is limited to domestic and wild animals (Maldonado et al., 2003; Maldonado \& Lanfredi, 2009), although the presence of Echinostoma paraensei eggs in feces has been reported from a mummified human body dated $560 \pm 40$ years before the present (Leles et al., 2014; Chai, 2019). In addition, E. paraensei is one of the most studied species in experimental models (Garcia et al., 2011; Garcia et al., 2012; Tunholi-Alves et al., 2011; Monte et al., 2016; Monte et al., 2019).

The opportunistic pathogen Pseudomonas aeruginosa is a bacterium that may be found infecting various taxa of organisms such as plants, nematodes, insects, protozoa and mammals (Morissette et al., 1996; Rehm, 2008). The association between infection by the trematode Schistosoma mansoni and bacterial infection by Staphylococcus aureus has been reported in human and experimentally acute schistosomiasis, leading to the development of pyogenic liver abscesses (Lambertucci et al., 2001; Teixeira et al., 2001; Lambertucci, 2010). The mechanical interaction established between S. mansoni and Salmonella typhimurium was previously demonstrated by scanning electron microscopy (Bouillard et al., 1983). In vitro analysis has also indicated the possibility of the action of other trematode species, e.g., Fasciola gigantica, as carriers of S. typhimurium (El Zawawy et al., 2002).

Co-infections with multiple pathogens including bacteria and intestinal helminths occur in different groups of hosts (Chard et al., 2019; Cortés et al., 2020; Su et al., 2014). This interaction can interfere in the dynamics of the disease, in the host's immune response and alter infection virulence (Jenkins et al., 2019; Long et al., 2019; Shen et al., 2019). Jenkins et al. (2019), suggest that the balance between immune-regulatory and pro-inflammatory bacterial taxa during schistosomiasis play a key role in determining the effective establishment of the infection, and/or severity of the disease resulting from the host's immune responses to infection.

Irwin \& Fried (1990) first reported the association between bacteria and the surface of encysted metacercariae of Echinostoma caproni. Later, Keeler et al., (2007), reported that several species of bacteria were present on the surface of metacercariae of $E$. caproni stored for further experimental use. However, there are no descriptions of the association between the presence of bacteria and the pathogenic effect of Echinostoma paraensei parasitism.

Here we describe the histopathological alterations in Swiss Webster mice experimentally infected by $E$. paraensei (Rio Bonito isolate) in association with the bacterium $P$. aeruginosa and the occurrence of pyogenic liver abscesses. 


\section{MATERIAL AND METHODS}

The isolate of E. paraensei utilized was obtained from naturally infected specimens of Nectomys squamipes (Cricetidae) captured in the

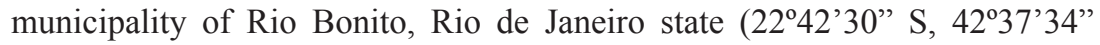
W). The life cycle of E. paraensei has been maintained in the Laboratory for Biology and Parasitology of Wild Reserve Mammals (LABPMR) at the Oswaldo Cruz Institute (IOC), Oswaldo Cruz Foundation (FIOCRUZ) in Rio de Janeiro, through passages in hamsters (Mesocricetus auratus) as definitive hosts, and snails Biomphalaria glabrata as intermediate hosts. The experiment was in line with the ethical procedures for animal treatment and the guidelines were approved by the Commission for Ethical Use of Animals at the Fundação Oswaldo Cruz (permit CEUA/L-029/2017).

Twenty adult female Swiss Webster mice were divided into two groups: (i) 15 mice infected with 20 metacercariae per animal by gavage obtained from experimentally infected snails; and (ii) 5 mice forming the control group, free of infection, receiving only dechlorinated water. The animals were euthanized 4 weeks post-infection. For euthanasia, the animals were anesthetized with an intramuscular injection of thiopental sodium, followed by intracardiac administration of potassium chloride, under the supervision of a licensed veterinarian. The intestines were then examined for helminths. The specimens collected from the small intestine were washed in Petri dishes with a physiological solution and stored in $70 \%$ alcohol.

Liver, bile duct and pancreas samples from the mice were fixed in Millonig's solution and processed for histopathological examination. Briefly, the samples were embedded in paraffin and sliced into $5 \mu \mathrm{m}$ sections (Humason, 1979). The material was stained with hematoxylin-eosin (HE) and Gomori's reticulin stain (GR). The slides were studied under a Zeiss Observer Z1 light microscope, and images were obtained using a Nikon Coolpix 4300 digital camera.

For bacterial identification, the purulent material located in the deepest part of the abscess in the liver was collected by aspiration using a syringe and needle. The samples were placed in individual tubes containing brain heart infusion (BHI) nutrient broth and incubated for a period of 24 hours in an aerobic atmosphere at $37^{\circ} \mathrm{C}$. After bacterial growth, the samples were spread on solid 5\% sheep blood agar medium to obtain bacterial colonies by incubation. The morphology of the specimens was observed, after which these underwent Gram staining. Subsequently, slides were assembled and examined under a light microscope with $100 \mathrm{X}$ immersion objective. All selected strains were re-isolated in Hektoen enteric Agar ${ }^{\circledR}$ (Oxoid). Biochemical bench tests were also carried out, followed by identification with the Vitek ${ }^{\circledR}$ automation system. 


\section{RESULTS}

The anatomopathological aspects were evident in the liver (Figure 1a), bile duct (Figure 1b) and duodenum (Figure 1c). The macroscopic alterations consisted of whitish suppurative pyogenic punctual lesions. These lesions were found in 11 of the 15 livers examined and were less frequent in the small intestine (3/15). In both cases the lesions were associated with the presence of the parasite. There were helminth clusters enlarging the bile ducts and a large quantity of mucus thickening the walls. The bacterial colonies observed in the purulent material were classified as Gram-negative rods, being distinct only in their morphology and arrangement. The colony's morphology and biochemical metabolism identified it as Pseudomonas aeruginosa.

The histological sections showed restricted inflammatory reaction around the bile ducts (Figure 2a), with mononuclear cells and low intensity of eosinophils and neutrophils (Figure 2b). Deposition of fibrotic material around the ducts was observed. The basal membrane of the ducts was thickened, with hyperplasia of the cell wall, presenting columnar aspect, together with lymphatic vessel congestion (Figure 2c). The presence of an E. paraensei embryonated egg was noted in the intrahepatic duct (Figure 2c). The hepatic parenchyma surrounding the bile ducts was inflamed and contained fibrotic material. The pancreatic ducts showed a similar pattern to that in the hepatic branch, with a slight inflammatory reaction (Figure 2d). No involvement of the Langerhans islands or the endocrine parenchyma was observed.

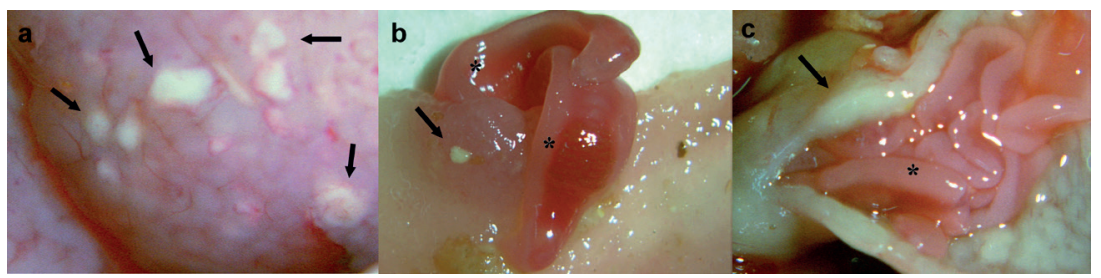

Figure 1. Macroscopic view. (a) Liver showing punctual lesions (pyogenic abscesses) (arrow) under Glisson's capsule. (b) Adult Echinostoma paraensei worms (*) attached to the duodenum surface, showing punctual lesions (pyogenic abscesses) (arrow). (c). Macroscopic view of bile duct showing enlargement and thickening of the walls with large quantity of mucus (arrow) and clusters of Echinostoma paraensei helminths $(*)$. 


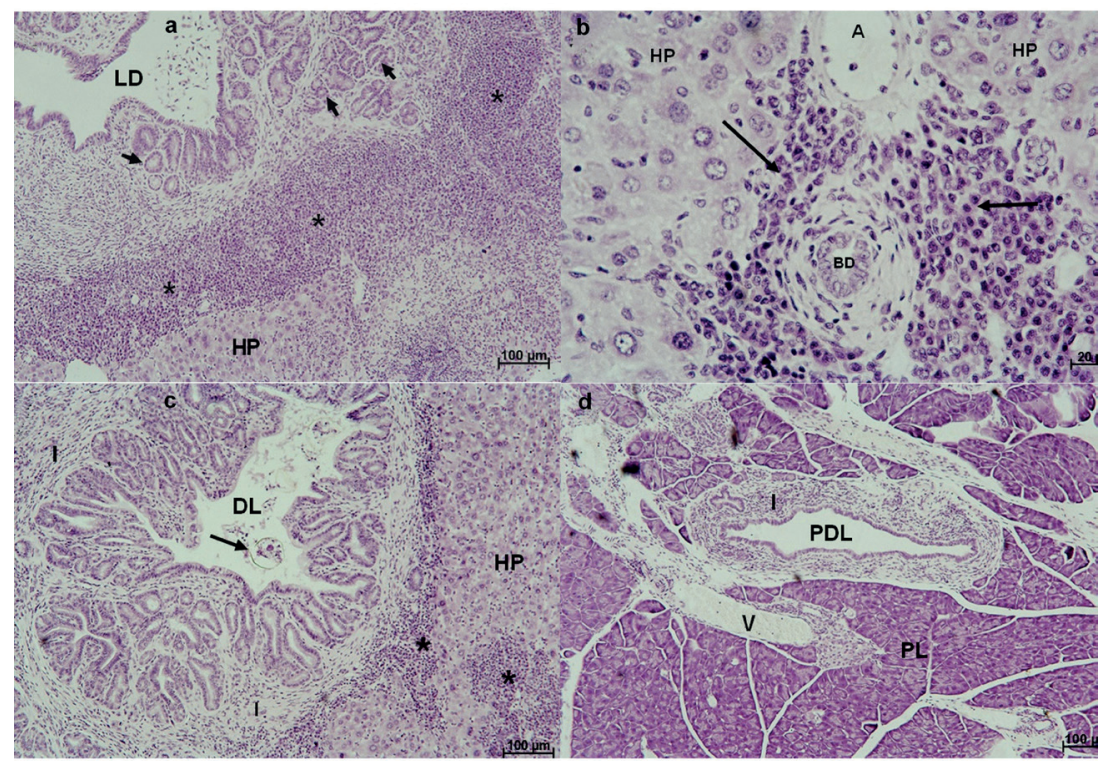

Figure 2. Histological sections. (a) Hepatic duct hyperplasia (arrows) and congestion of lymphatic vessels (*) in the hepatic periportal space. (DL = duct lumen; HP = hepatic parenchyma). (b) Macrophage monocytic infiltrate involving the duct of the intrahepatic portal space (arrows). (HP = hepatic parenchyma; $\mathrm{BD}=$ bile duct; $\mathrm{A}=$ artery). (c) Intrahepatic duct hyperplasia with macrophage monocytic infiltrate and congestion of peripheral lymphatic vessel to the duct (*). Arrow showing Echinostoma paraensei egg ( $\mathrm{I}=$ infiltrate; $\mathrm{DL}=$ duct lumen; $\mathrm{HP}=$ hepatic parenchyma). (d) Periductal inflammatory infiltrate in the pancreas. $(\mathrm{PL}=$ pancreatic lobe; $\mathrm{PDL}=$ pancreatic duct lumen; $\mathrm{I}=$ cell infiltrate; $\mathrm{V}=$ vein).

\section{DISCUSSION}

There are relatively few reports of histopathological findings associating bacterial and trematode infections (Abruzzi \& Fried, 2011; Lambertucci et al., 2001; Oyarzún-Ruiz et al., 2019).

Most studies report bacteria associated with the surface of encysted metacercariae or the tegument of adult digeneans (Nollen \& Nadakavukaren, 1974; Aho et al., 1991; Irwin \& Fried, 1990; Keeler et al., 2007). There are no reports on the pathological effects of concomitant infections. OyarzúnRuiz et al. (2019) described the presence of gastrointestinal helminths and histopathological lesions in black-necked swans (Cygnus melancoryphusm). Interestingly, in one swan infected by the nematode Epomidiostomum vogelsangi a Splendore-Hoeppli lesion was observed in the muscle wall of the gizzard, containing multiple bacterial colonies surrounded by eosinophils, giant cells and amorphous tissue. Also, in one swan infected by Echinostoma 
mendax there were Splendore-Hoeppli lesions associated with severe fibrosis and an inflammatory response in the serosa of the colon.

In an experimental study with E. paraensei, Garcia et al. (2011), determined histological and biochemical parameters in infected Rattus norvegicus (Wister). High levels of hepatic enzymes were noted in the first week of infection evidencing the pathogenic effect of the infection. Interestingly, the trematodes were recovered in the first portion of the small intestine (duodenum), differently from the present study in which worms were clustered in the ductal lumem. In addition, helminth migration to ectopic sites may have favored infection by opportunistic bacteria due to alterations in the host's immune system. In fact, helminthic infection can alter immune response to a bacterial pathogen contributing to its dissemination (Louhi et al., 2015; Long et al., 2019; Shen et al., 2019; Su et al., 2014).

Maldonado et al. (2005) reported different biological behaviors in the experimental infection of two isolates of E. paraensei collected from naturally infected Nectomys squamipes from two municipalities in Rio de Janeiro State, Brazil: Rio Bonito (RB) and Sumidoro (SU). The RB isolate presented a higher worm burden, longer life span and preferential clustering of the trematodes in the duodenum and bile duct, while in the SU isolate they were spread along the small intestine of the infected mice. Indeed, E. paraensei infection causes alterations in the hepatic function in experimentally infected rats, possibly due to partial obstruction of the bile duct by helminths (Garcia et al., 2011). These findings demonstrate that parasites express different behaviors, depending on the isolate, which may lead to a worsening of the infection itself or serve as a gateway to concomitant infections. Moreover, Chai et al. (1994), reported a human case of $E$. hortense infection, characterized by ulcerations of the duodenal mucosa. Therefore, this trematode can cause injury at the site of infection, forming a gateway for secondary infections.

This bacterium can exploit breaks in the host's defenses to initiate infection. One of the important entryways leading to septicemia is the intestinal tract. The virulence of the E. paraensei RB strain can increase the risk of bacterial infection through the ulcerations produced by the helminth. The opportunistic pathogen $P$. aeruginosa has been found in fecal or cecal samples of laboratory rats (Hayashimoto et al., 2013). On the other hand, the bacterium $P$. aeruginosa has also been isolated from Biomphalaria grabrata tissues (Cheng, 1986), which suggests a source of association between bacteria and metacercariae. The P. aeruginosa associated with the hepatic and duodenal suppurative lesions observed in the present study probably were transported by metacercariae of $E$. paraensei, since the snail B. glabrata is an important intermediate host for this trematode (Lie \& Bash, 1967). Thus, pyogenic abscesses can result from E. paraensei infection, depending on the trematode isolate. 


\section{ACKNOWLEDGEMENTS}

The authors would like to thank the Fundação Oswaldo Cruz (FIOCRUZ). This study was supported by the Conselho Nacional para o Desenvolvimento Científico e Tecnológico (CNPq) and Instituto Oswaldo Cruz (IOC/FIOCRUZ).

\section{CONFLICT OF INTEREST}

The authors declare that there is no conflict of interest.

\section{REFERENCES}

1. Aho JM, Uglem GL, Moore JP, Larson OR. Bacteria associated with the tegument of Clinostomum marginatum (Digenea). J Parasitol 77: 784-786, 1991.

2. Abruzzi A, Fried B. Coinfection of Schistosoma (Trematoda) with Bacteria, Protozoa and Helminths. Adv Parasitol 77: 1-85, 2011.

3. Bouillard C, Miegeville M, Vermeil C. Use of Scanning Electron Microscopy Coupled With Transmission Electron Microscopy in Comparative Studies of the Relation Between Schistosoma mansoni and Salmonella typhimurium. C R Seances Soc Biol Fil 177: 149-157, 1983.

4. Chai JY, Hong ST, Lee SH, Lee GC, Min YI. A case of echinostomiasis with ulcerative lesions in the duodenum. Korean J Parasitol 32: 201-204, 1994.

5. Chai JY. Human Intestinal Flukes: From Discovery to Treatment and Control. The Netherlands: Dordrecht, 2019. 521p.

6. Chard AN, Baker KK, Tsai K, Levy K, Sistrunk JR, Chang HH, Freeman, MC. Associations between soil-transmitted helminthiasis and viral, bacterial, and protozoal enteroinfections: a cross-sectional study in rural Laos. Parasit Vectors 12: 216-227, 2019.

7. Cheng TC. Biological control studies: Bacteria associated with moribund Biomphalaria glabrata (Mollusca) in the laboratory. J Invertebr Pathol 47: 219-224, 1986.

8. Cortés A, Rooney J, Bartley DV, Nisbet AJ, Cantacessi C. Helminths, hosts, and their microbiota: new avenues for managing gastrointestinal helminthiases in ruminants. Expert Rev Anti-infect Ther 18: 977-985, 2020.

9. El Zawawy LA, Ali SM, Mohamed ON, Allam SR. Bacterial-parasite interaction between Salmonella and each of Fasciola gigantica and Trichinella spiralis. J Egypt Soc Parasitol 32: 745-754, 2002.

10. Fried B, Graczyk TK. Echinostomes as experimental models for biological research. Springer Science \& Business Media, 2000. 22p.

11. Garcia JS, Hooper CS, Simões RO, Dos Santos, MAJ, Maldonado Jr A, Pinheiro J. Biochemical and histological responses of Rattus norvegicus (Wistar) infected by Echinostoma paraensei (Trematoda: Echinostomatidae). Vet Parasitol 178: 86-92, 2011.

12. Garcia JS, Pinheiro J, Hooper CS, Simões RO, Ferraz JS, Maldonado Jr A. Haematological alterations in Rattus norvegicus (Wistar) experimentally infected with Echinostoma paraensei (Trematoda: Echinostomatidae). Exp Parasitol 131: 300-303, 2012.

13. Hayashimoto N, Morita H, Ishida T, Yasuda M, Kameda S, Uchida R, Tanaka M, Ozawa M, Sato A, Takakura A, Itoh T, Kagiyama N. Current Microbiological Status of Laboratory Mice and Rats in Experimental Facilities in Japan. Exp Animal 62: 41-48, 2013. 
14. Humason GL. Animal Tissue Techniques, 4th ed. W.H. Freeman and Company: San Francisco, 1979.

15. Irwin SWB, Fried B. Scanning and transmission electron microscopic observations metacercariae of Echinostoma trivolvis and Echinostoma caproni during in vitro excystation. J. Helminthol. Soc Wash 57: 79-83, 1990.

16. Jenkins TP, Brindley PJ, Gasser RB, Cantacessi C. Helminth microbiomes - A hidden treasure trove? Trends Parasitol 35:13-22, 2019.

17. Keeler SP, Fried B, Hyffman JE. Association of bacteria with metacercariae cysts of Echinostoma caproni. Parasitol Res 101: 1131-1133, 2007.

18. Lambertucci JR, Rayes AA, Serufo JC, Nobre V. Pyogenic abscesses and parasitic diseases. Rev Inst Med Trop São Paulo 43: 67-74, 2001.

19. Lambertucci JR. Acute schistosomiasis mansoni: revisited and reconsidered. Mem Inst Oswaldo Cruz 105: 422-435, 2010.

20. Leles D, Cascardo P, Freire AS, Maldonado A, Sianto L, Araújo A. Insights about echinostomiasis by paleomolecular diagnosis. Parasitol Internat 63: 646-649, 2014.

21. Long SR, Lanter BB, Pazos MA, Mou H, Barrios J, Su C-W, Wang ZQ, Walker WA, HurleyBP, Shi HN. Intestinal helminth infection enhances bacteria-induced recruitment of neutrophils to the airspace. Scientific Reports 9: 15703, 2019.

22. Louhi KR, Sundberg LR, Jokela J, Karvonen A. Interactions among bacterial strains and fluke genotypes shape virulence of co-infection. Proc R Soc B 282: 20152097, 2019.

23. Lie JK, Bash PF. The life history of Echinostoma paraensei sp. n. (Trematoda: Echinostomatidae). J Parasitol 53: 1192-1199, 1967.

24. Maldonado AJr, Vieira GO, Lanfredi RM. Echinostoma luisreyi n. sp. (Platyhelminthes: Digenea) by light and scanning electron microscopy. J Parasitol 89: 800-808, 2003.

25. Maldonado Jr A, Zeitone BK, Amado LA, Rosa LF, Machado-Silva JR, Lanfredi RM. Biological variation between two Brazilian geographical isolates of Echinostoma paraensei. $J$ Helminthol 79: 1-8, 2005.

26. Maldonado Jr A, Lanfredi RM. Echinostomes in the Wild. In: Fried B, Toledo R. The Biology of Echinostomes: From the Molecule to the Community. Springer. New York, 2009. p.129-145.

27. Monte TCC, Garcia JS, Gentile R, Vasconcellos MC, Souza JG, Braga B, Maldonado Jr. A. In vivo and in vitro effects of the herbicide Roundup ${ }^{\circledR}$ on developmental stages of the trematode Echinostoma paraensei. Exp Parasitol 169: 43-50, 2016.

28. Monte TCC, Chometon TQ, Bertho AL, Moura VS, Vasconcellos MC, Garcia JS, FerrazNogueira R, Maldonado Júnior R, Faro MJ. Changes in hemocytes of Biomphalaria glabrata infected with Echinostoma paraensei and exposed to Glyphosate-based herbicide. J Invertebr Pathol 160: 67-75, 2019.

29. Morissette C, Francoeur C, Darmond-Zwaig C, Gervais F. Lung phagocyte bactericidal function in strains of mice resistant and susceptible to Pseudomonas aeruginosa. Infect Immun 64: 4984-4992, 1996.

30. Nollen PM, Nadakavukaren K. Megalodiscus temperatus: Scanning electron microscopy of the tegumental surfaces. Exp Parasitol 36: 123-130, 1974.

31. Oyarzún-Ruiz P, Paredes PME, Valenzuela G, Ruiz J. Gastrointestinal helminths and related histopathological lesions in black-necked swans Cygnus melancoryphus from the Carlos Anwandter Nature Sanctuary, Southern Chile. Rev Bras Parasitol Vet 28: 613-624, 2019.

32. Rehm BHA. Pseudomonas: model organism, pathogen, cell factory. John Wiley \& Sons. New Jersey, 2008. 397p.

33. Sah R, Khadka S, Hamal R, Poudyal S. Human echinostomiasis: a case report. BMC Res Notes 11: 1-6, 2018. 
34. Shen S-S, Qu X-Y, ZhangW-Z, Li J, Lv Z-Y. Infection against infection: parasite antagonism against parasites, viruses, and bacteria. Infect Dis Poverty 8: 49-51, 2019.

35. Sripa B, Kaewkes S, Intapan PM, Maleewong W, Brindley PJ. Food-borne trematodiases in Southeast Asia: epidemiology, pathology, clinical manifestation, and control. Adv Parasitol 72: 305-350, 2010.

36. Su L, Su C-Y, Qi Y, Yang G, Zhang M, Cherayil BJ, Zhang X, Shi HN. Coinfection with an intestinal helminth impairs host innate immunity against Salmonella enterica Serovar Typhimurium and exacerbates intestinal inflammation in Mice. Infect Immun 82: 3855-3866, 2014.

37. Teixeira R, Pfeilsticker FJ, Santa Cecilia GDC, Nobre V, Fonseca LP, Serufo JC, Coelho PMZ, Lambertucci JR. Schistosomiasis mansoni is associated with pyogenic liver abscesses in the state of Minas Gerais, Brazil. Mem Inst Oswaldo Cruz 96: 143-146, 2001.

38. Tunholi-Alves VM, Tunholi VM, Gôlo P, Lustrino D, Maldonado Jr A, Bittencourt VREP, Rodrigues MLA, Pinheiro J. Lipid levels in Biomphalaria glabrata infected with different doses of Echinostoma paraensei miracidia. Exp Parasitol 128: 212-216, 2011. 